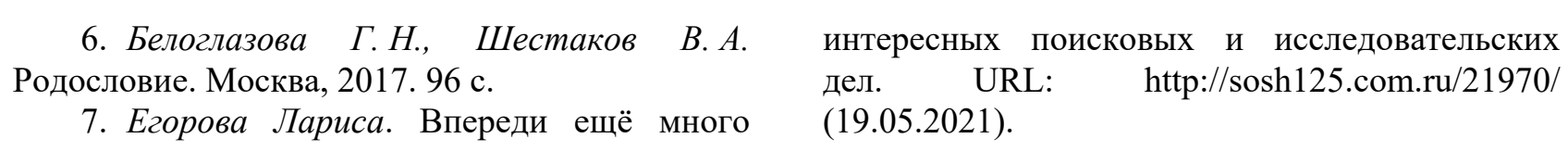

УДК 37.013:159.924.24

DOI: $10.32340 / 2514-772 X-2021-1-09-12$

И. Л. Борзенко, кандидат педагогических наук Алтайский государственный институт культуры (Барнаул, Россия) irinab77@yandex.ru

Л. А. Комаристая, кандидат исторических наук, доцент Алтайский государственный институт культуры (Барнаул, Россия) super.humanity2015@yandex.ru

3. Н. Лукьянова,
кандидат психологических наук, профессор
Алтайский государственный институт культуры (Барнаул, Россия)
lukyanova1948@inbox.ru

\title{
ПРЕЕМСТВЕННАЯ СВЯЗЬ ГУМАНИТАРНОГО ЗНАНИЯ И РАЗВИТИЯ ТВОРЧЕСКИХ СПОСОБНОСТЕЙ (К ПОСТАНОВКЕ ПРОБЛЕМЫ)
}

Аннотация. В работе рассматриваются проблемы формирования личности методом её участия в творческой деятельности. Поднимается проблема определения способов влияния гуманитарного знания на развитие личности. Анализируется роль гуманитарных дисциплин в развитии интереса к творческой деятельности, а также поднимается проблема обратного влияния участия в этой деятельности на проявление интереса к учебным дисциплинам гуманитарного цикла, побуждения нового осмысления их содержания.

Ключевые слова: гуманитарное знание, творческая деятельность, личность, преемственность, культура, способности.

В современном образовании важным направлением его развития является переход на новые образовательные стандарты. Их задача - это создание такой социальнопедагогической среды, которая поможет в формировании и развитии обучающихся, в реализации своих проектов и инициатив. Сегодня важнейшим приоритетом образования выступает обеспечение качества образования. А чтобы оно было качественным, нужны специально созданные условия. И одним из таких условий является непрерывность образования. До недавнего времени в практике образования речь шла о преемственности обучения, сегодня это понятие трансформировалось в преемственность образования. Это то, что как раз и создает непрерывный образовательный процесс. Преемственность в образовании может проявляться во взаимодействии задач, содержания, методов и технологий обучения и воспитания. В своей статье мы остановимся на преемствен- ности, которая проявляется во взаимосвязи гуманитарного знания и развития творческих способностей.

Проблема преемственности обучения школьного, досугового, средне-специального и других, разрабатывалась в психологопедагогической науке ещё в прошлом столетии. С. Л. Рубинштейн говорил о необходимости учёта в овладении знаниями собственной деятельности ребёнка, его актуализации своего познавательного опыта. Он утверждал: «Всякая попытка воспитателя-учителя «внести» в ребёнка познание и нравственные нормы, минуя собственную деятельность ребёнка по овладению ими, подрывает... самые основы здорового умственного и нравственного развития ребёнка, воспитания его личностных свойств и качеств» $[1$, c. 192-193]. В этом отношении важна роль житейского опыта, даже если он невелик.

Авторы более позднего времени Ю. В. Сенько, В. Э. Тамарин и другие [2] гово- 
рят о роли познавательного опыта в приобретении нового знания, в выражении себя как формирующейся личности. При этом новые знания приобретаются не только в учебной или учебнонаучной сфере, но и в досуговой, где учащиеся могут проявить себя с художественнотворческой стороны при изготовлении различных предметов материальной культуры (вышивка, гончарные изделия, работа по дереву и т. п.).

Преемственность как дидактическая категория явилась объектом исследования различных ученых (Ю. К. Бабанский, Ш. И. Ганелин, Б. С. Гершунский, С. М. Годник, В. В. Давыдов, М. А. Данилов, Л. В. Занков, В. К. Кудрявцев, Э. М. Кузьмина, В. Н. Максимова, В. Э. Тамарин, Д. Б. Эльконин и др.) [3, с. 1102].

Вопросы преемственности решались в диссертационных исследованиях С. В. Архиповой [4], Р. М. Зайниева [5], С. Н. Рягина [6]. Научные статьи, освещающие различные стороны проблемы преемственности и взаимосвязи, опубликовали Т. М. Добродомова, М. Е. Добрускин, О. В. Кожевникова, Т.Н. Логачева, Е. И. Савина, В. С. Сенашенко, Е. А. Тагаева и др. [7].

Реализацию принципа преемственности можно проследить и при анализе взаимосвязи гуманитарного знания и развития творческих способностей. Сегодня от школьников и будущих студентов требуют нестандартного решения профессиональных задач. Технология проектного обучения, частично реализуемая в школе и имеющая свое продолжение в вузе, как нельзя лучше формирует творческие способности. Гуманитарное знание, которое требует от обучающихся умения думать, пояснять получаемые итоги, сопоставлять, выстраивать причинно-следственные связи, обобщать, делать выводы, как нельзя лучше способствует развитию творческих навыков.

В настоящее время всё более зримой становится необходимость повышения уровня гуманитарного образования в целях оптимального развития личности школьника и студента. К сожалению, этому не способствуют сокращение в школьных и вузовских учебных планах количества часов, отводимых на изучение дисциплин гуманитарного цикла, отношение в ряде учебных заведениях к общенаучным дисциплинам как к второстепенным, чрезмерное увлечение молодёжи гаджетами и Интернетом, что может блокировать возможности полноценного интеллектуального развития.

Нельзя не признать, что усвоение багажа знаний гуманитарного образования, представ- ление о вековой культуре общества формируют облик будущего специалиста не только как грамотного в своей области человека, но и, как правило, человека с устойчивой нравственной позицией. В этом отношении перед преподавателями общегуманитарных дисциплин (история, литература, иностранный язык, психология, педагогика и др.) стоят задачи углубления, нового осмысления полученных в школе или колледже знаний, поиск возможностей усвоения новых знаний и сохранения общекультурных традиций как историко-культурного наследия.

Каждый педагог, учитывая специфику и содержание изучаемой дисциплины, ориентируется, прежде всего, на возможности своего индивидуально-личностного способа и метода преподавания. Но при этом, как нам кажется, всё же можно выделить основные приоритетные составляющие, к содержанию которых можно обратиться каждому преподавателю дисциплин гуманитарного цикла:

«Первое, и самое главное: найти точки соприкосновения изучаемых дисциплин, специальных и общегуманитарных, являющихся отправным материалом для формирования личности будущего специалиста, профессиональнограмотного, высококультурного, гармонично развитого человека.

Вторым фактором может быть попытка соединения основных положений изучаемых дисциплин, направленных на освоение того или иного курса с целью взаимодополнения учебного материала.

И третий момент, может быть наиболее важный в практическом плане: переработать теоретический материал, чтобы необходимые данные изучаемой гуманитарной дисциплины могли войти в виде методических рекомендаций в своеобразную «профессиональную копилку» $[8$, c. 69$]$.

Преподаватель гуманитарных дисциплин имеет возможности вести свой предмет с учётом особенностей и специфики будущей специальности обучающегося в конкретном учебном процессе.

Помимо этого, преподаватель может опираться на опыт творческой деятельности, полученный студентом вуза ещё в школе, во время занятий внеурочной деятельностью или в рамках дополнительного образования. Значимым фактором является проведение научнопрактических конференций, других форм взаимодействия, где школьники как будущие студенты могут представить и обсудить со специалистами свои работы. Данный опыт может слу- 
жить для них ориентиром в принятии решения о выборе будущей профессии. Кроме того, подобная деятельность формирует исследовательскую компетенцию, развитие которой имеет свое продолжение в вузе. Проекты школьников, имея в своей основе гуманитарное знание, готовят будущих студентов к проектной деятельности, которая является одной из основных в высшей школе.

Подобная связь вуза и школы реализуется, например, краевой конференции «Мои первые шаги в науку», основателем которой был доктор педагогических наук, профессор В. И. Матис, а многолетним руководителем является один из авторов данной статьи, преподаватель кафедры гуманитарных дисциплин Алтайского государственного института культуры, кандидат педагогических наук И. Л. Борзенко.

Изначально одной из основных задач организации такой работы было выявление потенциальных возможностей школьника, его дальнейшее развитие как творческой личности в выбранной им профессии, независимо от того, будет ли она связана с его сегодняшним творческим увлечением. Преподаватели кафедры гуманитарных дисциплин, отбирая работы для участия в научно-практической конференции, получают бесценный опыт анализа творческой деятельности с его наглядным результатом (изготовление гончарных изделий, художественная вышивка, изобразительное мастерство и др.). Они имеют при этом возможность увидеть не только материально-художественное воплощение знаний и умений ученика, но и его способность осмыслить исторические корни, особенности конкретного региона, развитие культуры в регионе в различные исторические эпохи, осмыслить творчество местных художников, мастеров, уникальную роспись и т. д.

Представление об истории родной страны не только как об учебном предмете, но и о живших или живущих людях в конкретном историческом периоде ориентируют учащихся на более глубокое осмысление событий прошедшего времени. История как учебная дисциплина, дополненная знанием истории «малой Родины», становится не формальной с обязательным усвоением дат и имён великих людей, а той живой структурой связи поколений, которая побуждает взрослеющего человека находить всё новые интересные моменты событийных периодов с их отражением в художественном творчестве. В вузовской системе такому бывшему школьнику интереснее воспринимать дисциплины исторического цикла, так как усвоение осуществляется не с механическим запоминанием, а с осмыслением глубины каждого временного отрезка.

Л. А. Комаристая отмечает, что формирование у школьников, а затем «студентов элементов исторического сознания и исторического мышления» можно определить в качестве одной из приоритетных целей преподавания истории. Историческое сознание в той или иной мере присуще любой личности. Но формирование исторического мышления, как «способности рассматривать события и явления с точки зрения их исторической обусловленности» [9, c. 135] имеет свои особенности у студентов творческих вузов, вытекающие из их предыдущего опыта художественно-творческой деятельности, которые нуждаются в дополнительном изучении и осмыслении.

В психолого-педагогическом плане ценный материал для постановки вопросов взаимосвязи и преемственности гуманитарного знания и развития творческих способностей может дать анализ участия одного из авторов данной статьи в работе жюри межрегионального конкурса «Мои этнические корни» [10]. Участие в данном конкурсе не только развивает исследовательский интерес у школьников, но и естественным образом воспитывает чувство патриотизма, формируя культуру межнационального общения.

В то же время учебные курсы дисциплин психолого-педагогического цикла в высшем учебном заведении дают возможность студенту увидеть себя как бы «со стороны», поскольку различные методики оказывают помощь в изучении собственной личности, её самооценки, что для людей творческой направленности всегда имело огромное значение. Теоретический материал служит при этом основой в дальнейшем совершенствовании личности, определений способов её развития. Участие преподавателей педагогики и психологии (и смежных дисциплин) в проведении индивидуальных и групповых консультаций по различным проблемам психолого-педагогической науки и практики позволяет студентам более успешно реализовать себя в овладении ими навыками будущей художественной деятельности.

Следует также отметить, что навыками эффективного педагогического общения в русле поставленной проблемы взаимосвязи гуманитарного знания и творческого опыта, необходимо владеть и преподавателям специальных дисциплин. Обобщая большой накопленный опыт, профессор 3. Н. Лукьянова рекомендует учитывать довузовский опыт обучающихся, опреде- 
лять ориентированную профессиональную самооценку личности, которая может изменяться, находить оптимальный индивидуальный стиль работы, изучать проблему общения и формирования самооценки личности, педагогу обращаться к собственному опыту, определяя наиболее эффективные методы и технологии межличностного взаимодействия со студентами $[11$, c. 66].

Рассмотренные проблемы побуждают авторов приступить к дальнейшему исследованию поисков взаимосвязи художественного творчества и содержания гуманитарного образования, а также к определению наиболее эффективных методов и приёмов внедрения такого единения в учебный процесс.

Список литературы

1. Рубинитейн С. Л. Проблемы общей психологии. Москва, 1973. 489 с.

2. Сенько Ю. В., Тамарин В. Э. Обучение и жизненный познавательный опыт. Москва, $1989.77 \mathrm{c}$.

3. Федотова Л. Е. Преемственность уровней образования в условиях ФГОС // Здоровье основа человеческого потенциала: проблемы и пути их решения. 2020. № 3. Том 15. С. 10991103.

4. Архипова С. В. Преемственность в образовании: социологический анализ: автореф. дис. ...канд. социол. наук. Екатеринбург, 2009. 19 с.

5. Зайниев Р. М. Преемственность профессионально-ориентированного содержания математического образования в системе «школа- колледж-вуз»: автореф. дис. ... д-ра пед. наук. Ярославль, 2012. 43 с.

6. Рягин С.Н. Преемственность среднего общего и высшего профессионального образования в условиях их системных изменений: автореф. дис. ... д-ра пед. наук. Москва, 2010. 43 с.

7. Кожевникова О.В. Преемственность в образовании: представления участников образовательной системы о выпускнике школы // Педагогическое образование в России. 2013. № 1. C. 86-93.

8. Лукьянова 3. Н. Психологические условия формирования позитивного отношения у студентов образовательных учреждений к предметам общегуманитарного цикла // Мир науки, культуры, образования. 2018. № 4. C. $68-70$.

9. Комаристая Л. А. Формирование исторического мышления и проблемы повышения качества образования в условиях совершенствования ФГОС // Качество образования в сфере культуры и искусств в условиях реализации ФГОС ВО. Барнаул, 2015. C. $135-138$.

10. Борзенко И. Л. Конкурс "Этнические корни" как средство развития интереса к национальной культуре // Проектно-технологические и организационно-методические аспекты деятельности этнокультурных коллективов. Барнаул, 2014. С. 124-130.

11. Лукьянова 3. Н. Влияние самооценки личности на характер общения школьников и студентов. Барнаул, 2020. 164 с.

\section{КУЛЬТУРНО-ХОРЕОГРАФИЧЕСКОЕ НАСЛЕДИЕ АЛТАЙСКОГО КРАЯ: СОХРАНЕНИЕ И РАЗВИТИЕ ШКОЛЫ КЛАССИЧЕСКОГО ТАНЦА}

Аннотация. В статье рассматривается роль классического танца в контексте культурного наследия Алтайского края, необходимость изучения классического наследия балета в современном образовании хореографов, определяется его важность в системе хореографического обучения участников любительских и профессиональных хореографических коллективов различной жанровой направленности в условиях регионального культурного пространства. Раскрывается деятельность ведущих педагогов-хореографов по обучению воспитанников сложным формам классического жанра танца. Выявляются возможности классического танца в формировании системы профессиональных компетенций будущих педагогов-хореографов. 